\title{
Morphological characteristics of the digestive tract of Schizodon knerii (Steindachner, 1875), (Characiformes: Anostomidae): An anatomical, histological and histochemical study.
}

\author{
MARCELLA L. DOS SANTOS ${ }^{1}$, FÁBIO P. ARANTES ${ }^{1}$, \\ KLEBER B. SANTIAGO ${ }^{2}$ and JOSÉ E. DOS SANTOS ${ }^{1,3}$ \\ ${ }^{1}$ Programa de Pós Graduação em Zoologia de Vertebrados da PUC Minas, Av. Dom José \\ Gaspar, 500, Coração Eucarístico, 30535-610 Belo Horizonte, Minas Gerais, Brasil \\ ${ }^{2}$ Companhia de Desenvolvimento dos Vales do São Francisco e do Parnaíba, Av. Geraldo \\ Rodrigues dos Santos, s/n, Satélite, 39205-000 Três Marias, Minas Gerais, Brasil \\ ${ }^{3}$ PET Biologia PUC Minas, Av. Dom José Gaspar, 500, CoraçãoEucarístico, \\ 30535-610 Belo Horizonte, Minas Gerais, Brasil
}

Manuscript received on May 26, 2014; accepted for publication on October 25, 2014

\begin{abstract}
The digestive tracts of 44 specimens of Schizodon knerii were studied using anatomical, histological and histochemical techniques. The mouth has terminal position, the lip epithelium is squamous stratified with mucous, claviform cells and taste buds, teeth have an incisive form and the tongue has a stratified squamous epithelium with mucous cells and taste buds. The oropharynx cavity is formed by gill apparatus and pharyngeal teeth. The oesophagus presented pleated mucosa, a stratified squamous epithelium with mucous cells, oesophageal glands and taste buds. The stomach presented cardiac, fundic and pyloric regions, simple prismatic epithelium with tubular glands, with none in the pyloric region. The intestine contains 1115 pyloric caeca, a simple prismatic epithelium with brush border, goblet cells and lymphocytes. Mucosal cells, oesophageal glands and goblet cells reacted positively to PAS, amylase + PAS, Ab pH 2.5 and Ab pH 0.5 . Gastric prismatic cells reacted positively to PAS, amylase + PAS, but only those in the pyloric region reacted positively to $\mathrm{Ab} \mathrm{pH} 2.5$ and $\mathrm{Ab} \mathrm{pH} 0.5$. The results improve the understanding of the anatomy of $S$. knerii feeding habits and the presence of mucosubstances in the epithelium, highlights the importance of glycoproteins for passing food through the digestive tract.
\end{abstract}

Key words: Anostomidae, digestive tract, fish, morphology.

\section{INTRODUCTION}

Morphological studies of the digestive tract of fish are considered effective tools for understanding the mechanisms of ingestion, digestion and absorption of food, and have recently been carried out for several species (Xiong et al. 2011, Germano et al. 2013,

Correspondence to: José Enemir dos Santos

E-mail: enemir@pucminas.br
Løkka et al. 2013). The digestive system of fish show distinctive morphological and functional diversity (Diaz et al. 2003), due to the high biodiversity in teleost fish and the different positions they occupy in the food chain (Santos et al. 2007).

In fish, the oral and oropharyngeal cavities play important roles in selecting, seizing and directing food to the oesophagus (Al-Hussaini 
1946, Rodrigues et al. 2006, Wilson and Castro 2011). Anatomical and histological studies enable us to relate those cavities to the eating habits (Al-Hussaini 1946) and the food processing mechanisms (Rodrigues et al. 2006, Hanke et al. 2008). The oesophagus, stomach, intestine and pyloric caeca are tubular organs that enable food conveyance, storage, digestion and absorption (Seixas-Filho et al. 2000, Albrecht et al. 2001, Rodrigues and Menin 2008, Wilson and Castro 2011). Histologically, those regions of the digestive tract present differences among species. However, they present a wall consisting of four layers: mucosa, submucosa, muscularis and serosa (Albrecht et al. 2001, Xiong et al. 2011, Wilson and Castro 2011). Studies of those layers have indicated that the main differences occur in the epithelium and are related to the feeding habits (Albrecht et al. 2001), type of food ingested (Germano et al. 2013), absorption and production of mucosubstances (Albrecht et al. 2001, Santos et al. 2007).

The Anostomidae family consists of 12 genera and 138 species distributed throughout southern Central America and South America (Garavello and Britski 2003), and shows some variation in food habits (Guisande et al. 2012).

Schizodon knerii, popularly known as "piau branco", is endemic to the São Francisco River basin (Britski et al. 1986), and is important for human feeding and professional fishing (Sato and Barbieri 1982, Barbosa and Soares 2009). It has herbivorous feeding habits (Alvim and Peret 2004) and presents first sexual maturity with a standard length of $14.5 \mathrm{~cm}$ for females and $12.3 \mathrm{~cm}$ for males (Soares et al. 1996). However, there are no studies on the morphology of its digestive tract.

This study analyzed and established the morphological characteristics of the digestive tract of S. knerii using anatomical, light microscopy and histochemical techniques, aiming to increase the knowledge about its biology, since the species is important for commercial fishing in the Três Marias region.

\section{MATERIALS AND METHODS}

Forty-four adult specimens of $S$. knerii of both sexes were collected in the São Francisco River

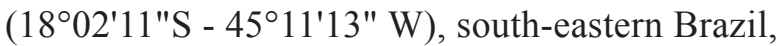
between January and December 2012. Sampling was conducted using gillnets with mesh sizes with a distance of 4 to $8 \mathrm{~cm}$ between opposite knots. Thirty specimens (12 males and 18 females) were fixed in 10\% formalin for 12 hours and transferred to $70 \%$ ethanol, and were then used for anatomical study and statistical analysis. Fragments from different regions of the digestive tract of ten specimens were collected for histological study. Four specimens were prepared and deposited in the fish collection of the PUC Minas Science Museum under number MCNI N.0124. The handling of the specimens followed the guidelines of CONCEA's standards of practice for euthanizing animals (Brasil 2013), and fish collection was authorised by the State Forest Institute of Minas Gerais (license No. 183085-1561-2012).

\section{ANATOMY}

For each specimen, the standard length (SL; cm) and body weight $(\mathrm{g})$ were recorded. The digestive tract was dissected, and the lengths $(\mathrm{mm})$ of the oral cavity, oesophagus, intestine (CI; $\mathrm{mm}$ ) and pyloric caeca were measured and quantified. Subsequently, the intestinal coefficient (CO) was calculated using the equation: $\mathrm{CO}=\mathrm{CI} / \mathrm{SL}$, according to Angelescu and Gneri (1949). To check the adaptations of the oral cavity in relation to food capture and seizure, the following were described: the shape of the lips and tongue, the morphology of the pharyngeal teeth and the type of pharyngeal teeth apparatus. The structures of the digestive tract: oral cavity, oesophagus and pyloric caeca were measured using a digital caliper (DIGIMESS - accuracy of $0.01 \mathrm{~mm}$ ). For intestine measurement, a tape measure (MACROLIFE) was used to promote more accuracy when measuring length and flexure. All structures were analyzed using an Olympus $\mathrm{SZ}-11$ stereomicroscope. 


\section{LIGHT MICROSCOPY}

Fragments of the lips, tongue, oesophagus, stomach (cardiac, fundic and pyloric), intestine (cranial, middle and caudal) and pyloric caeca were fixed in Bouin's fluid for $6 \mathrm{~h}$ and subsequently subjected to histological techniques with haematoxylin-eosin (HE) and Masson's trichrome (TG) stains. Some sections were processed for carbohydrate and protein analysis, following Pearse (1985): periodic acid-Schiff (PAS) for carbohydrates with 1:2 glycol groups; glycogen, neutral glycoproteins and sialomucin; salivary amylase $\left(30 \mathrm{~min}\right.$ at $\left.37^{\circ} \mathrm{C}\right)$ for glycogen digestion, followed by PAS (amylase + PAS), performing the counter test with rat intestine; alcian blue $\mathrm{pH} 2.5$ (Ab $\mathrm{pH}$ 2.5) for carboxylated and sulphated glycoconjugate acids including sialomucines, alcian blue $\mathrm{pH} 0.5(\mathrm{Ab} \mathrm{pH} 0.5)$ to sulphated glycoconjugates.

\section{STATISTICAL ANALYSIS}

In order to check for the occurrence of sexual dimorphism for the specimens, standard length, oral cavity length, oesophagus length and intestine length, and pyloric caeca quantification were tested for normality assumption by the Lilliefors test. Data with normal distribution were subjected to Student's T-test, non-normally distributed data were subjected to the Mann - Whitney nonparametric test. All analyses were performed using BioStat 5.0 package $(\mathrm{p}<0.05)$.

\section{RESULTS}

The male specimens presented a standard length of $23.09 \pm 2.71 \mathrm{~cm}$ and body weight of 262.16 $\pm 94.11 \mathrm{~g}$, the female measured $23.38 \pm 2.98$ $\mathrm{cm}$ of standard length and $289.38 \pm 119.31 \mathrm{~g}$ of standard body weight.

The digestive tract of $S$. knerii consists of the oral cavity, oropharynx, oesophagus, stomach, pyloric caeca, intestines and anus (Fig. 1A). The oral cavity was $29.30 \pm 2.48 \mathrm{~mm}$ in length and presented terminal mouth, lips, teeth and tongue. The lips are thin, and have a stratified squamous epithelium, with taste buds as well as mucous and claviform cells (Fig. 1E). The taste buds are scattered at the apex of the epithelium and are supported by the dermis. The mucous cells showed a basal nucleus and mucus-filled cytoplasm, the claviform cells showed a central nucleus and acidophilic cytoplasm. The teeth are pleurodont and the dental arch consists of 8 upper and 8 lower incisiform teeth (Fig. 1C). The tongue has a rectangular shape with rounded apex and relates caudally to the rostral end of the first hyoid arch (Fig. 1B). Histologically, it shows a stratified squamous epithelium, with taste buds and mucous cells (Fig. $1 F)$. The oropharynx cavity has a triangular shape and is composed of a strainer gill and pharyngeal teeth apparatus. The gill apparatus consists of five pairs of gill arches. The branchial arches I, II, III and IV have ventral and dorsal segments, while the branchial arch V contains only a ventral one. The pharyngeal dental apparatus is located in the caudal portion of the oropharynx cavity and consists of a ventral triangular plate and two dorsal oval dental plates, both with unciform denticles (Fig. 1A, 1B).

The oesophagus, a tubular organ, measured $13.39 \pm 3.46 \mathrm{~mm}$ in length, presented a longitudinal pleated mucosa and connects the oropharynx cavity to the stomach (Fig. 1A). Histologically, the oesophagus consists of the following layers: mucosa, submucosa, muscularis and serosa (Fig. $1 \mathrm{G})$. The epithelium is stratified squamous, with epithelial cells interspersed by mucous cells, branched tubuloacinar oesophageal glands and taste buds only in the cranial region (Fig. 1H). The submucosa layer consists of loose connective tissue with fat cells and blood vessels. The muscular layer is composed of skeletal muscle tissue with muscular fibres arranged longitudinally on the inner sublayer, and in a circular shape on the outer one. The serosa is the outermost layer and consists of dense connective tissue and mesothelium. 

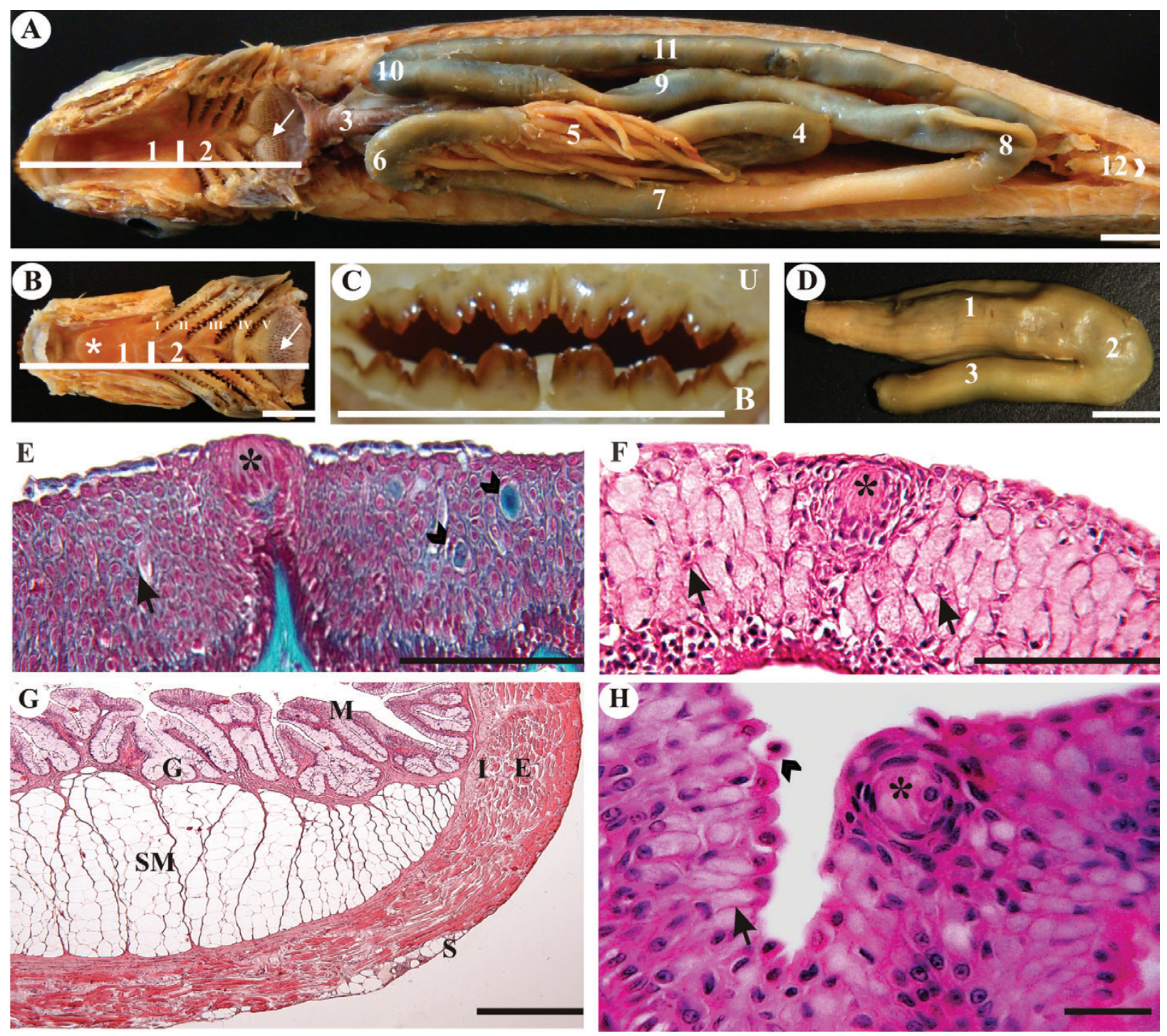

Fig. 1 - Structures of the digestive tract of S. knerii: (A). Oral cavity roof (1), oropharyngeal cavity (2), pharyngeal teeth apparatus (arrow), white bar indicates the boundary between the oral and the oropharyngeal cavities, oesophagus (3), fundic (4), pyloric caeca (5) pyloric flexure (6), cranial intestine (7), caudal flexure (8), midintestine (9), cranial flexure (10), caudal intestine (11), anus (12) $($ bar $=1 \mathrm{~cm})$. (B). Floor of the oral cavity (1) and oropharynx (2) showing: tongue (asterisk), branchial arches (I to V), pharyngeal teeth apparatus (arrow) (bar $=1 \mathrm{~cm})$. (C). View of the upper (U) and bottom (B) incisiformes rostral teeth (bar $=1$ $\mathrm{cm}$ ). (D). Side view of the stomach, showing the cardiac (1), fundic (2) and pyloric (3) regions (bar = $1 \mathrm{~cm})$. (E). Longitudinal section upper lip showing: taste buds (asterisk), mucosal cell (arrow), claviform cells (arrowheads), TG (bar $=100 \mu \mathrm{m})$. $(\mathbf{F})$. Cross section of the tongue showing: taste bud (asterisk), mucosa cell (arrow), HE (bar $=100 \mu \mathrm{m})$. (G). Histological organization of the oesophagus: Cross section showing mucosa (M), submucosa (SM), branched tubuloacinar oesophageal glands (G), internal muscular layer (I), external muscular layer $(\mathrm{E})$, serosa $(\mathrm{S})$, HE (bar $=500 \mu \mathrm{m})$. (H). Mucosa layer of the oesophagus showing: taste bud (asterisk), mucosa cell (arrow), epithelial cells (arrowhead), HE (bar $=100 \mu \mathrm{m})$.

The cecal type stomach has a "U" shape, with three well-defined regions: cardiac, fundic and pyloric (Fig. 1D). Histologically, the three regions of the stomach have mucosa, submucosa, muscularis and serosa layers (Fig. 2A, 2B, 2C). The epithelium is prismatic with cells showing an oval nucleus and acidophilic cytoplasm. The gastric glands are tubular, with oxynthic and peptic cells, 
supported on the lamina propria and were observed in the cardiac and fundic regions (Fig. 2D, 2E). The submucosa layer consists of blood vessels and dense connective tissue rich in collagen fibres. The muscular layer consists of two sub-layers: an internal one, with smooth muscle fibres oriented in a circular way, and an external one, with longitudinal smooth muscle fibres, both interspersed with loose connective tissue. Thickening of the inner circular muscular layer occurred in the pyloric region. The serosa layer presented loose connective tissue and mesothelium.

The intestine measured $302.1 \pm 47.15 \mathrm{~mm}$ in length, with an intestinal coefficient of $1.30 \pm$ 0.17 . The intestine consists of the pyloric flexure, with 11-15 pyloric caeca, initial descending loop (cranial intestine), caudal flexure, ascending loop (mid-intestine), cranial flexure, descending terminal loop (caudal intestine) and the anus (Fig. 1A). The pyloric caeca exhibited a finger-like shape and measured $24.5 \pm 9.1 \mathrm{~mm}$ in length. Under a light microscope, the three regions of the intestine and pyloric caeca showed similar structural organisation, consisting of the mucosa, submucosa, muscularis and serosa layers (Fig. 3A, 3C). The epithelium is a simple prismatic, with brush border, prismatic cells showing an elongated nucleus and acidophilic cytoplasm, intermingled with goblet cells and lymphocytes (Fig. 3B, 3D). The submucosa layer presented dense connective tissue and blood vessels, which follow the folds of the mucosa. The muscular layer consisted of smooth muscle tissue with fibres circumferentially oriented in the internal sub-layer, and longitudinally on the external one, both showed loose connective tissue. The serosa layer exhibited loose connective tissue and mesothelium.

The mucous cells, oesophageal glands and goblet cells reacted positively to PAS, amylase + $\mathrm{PAS}, \mathrm{Ab} \mathrm{pH} 2.5$ and $\mathrm{Ab} \mathrm{pH} 0.5$, indicating neutral glycoproteins and acid glycoconjugate sulphates and carboxylic (Table I). The prismatic cells of the stomach reacted positively to both PAS and amylase
+ PAS, showing the presence of neutral glycoproteins (Table I), and only the prismatic cells of the pyloric region reacted positively to $\mathrm{Ab} \mathrm{pH} 2.5$ and $\mathrm{Ab} \mathrm{pH}$ 0.5 , indicating the presence of carboxylated and sulphated glycoconjugate acids (Table I).

The statistical analysis performed in this study indicated that there was no significant difference between the sexes regarding the features analyzed. Therefore, S. knerii showed no sexual dimorphism in the structures measured in the digestive tract $(\mathrm{P}>0.05)$.

\section{DISCUSSION}

Studies on the morphology of the digestive tract of fish have been conducted by several authors, from the classic works of Al-Hussaini (1949), Angelescu and Gneri (1949) and Bértin (1958), to the more recent ones which employed more refined techniques such as histochemistry and electron microscopy, for example those of Xiong et al. (2011) and Løkka et al. (2013).

According to Xiong et al. (2011), Rodrigues and Menin (2005) there should be more researches on the processes of nutrients digestion, such as this paper that makes it possible to describe relevant information on the species, which is important for human feeding and professional fishing (Sato and Barbieri 1982, Barbosa and Soares 2009). It is important to highlight that there are no studies on this specie's digestive tract morphology nor studies that analyze, in such extension, all organs involved in ingestion, digestion and absorption. All of that information is shown here and are essential and applicable for the management of this species.

In Teleosts, the position of the mouth can be correlated to feeding habits (Rodrigues et al. 2006). The species under study is herbivorous (Alvim and Peret 2004) and presented the mouth in a terminal position, similar to other species of the same genus, such as Schizodon borellii and Schizodon altoparane (Ferretti et al. 1996), but unlike Schizodon nasutus, which has a sub-terminal mouth, despite being 

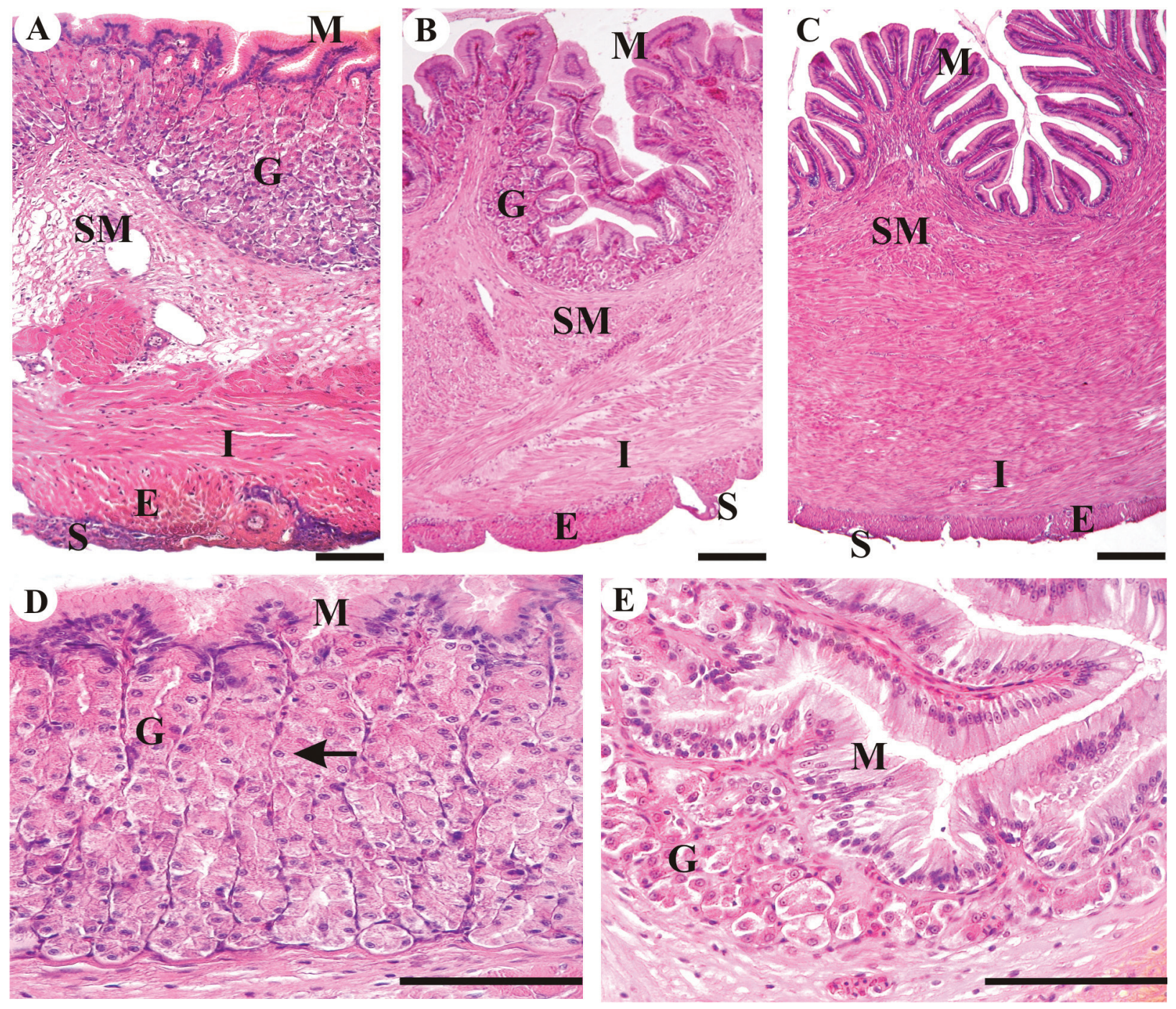

Fig. 2 - Histological organization of the three regions of the stomach: (A). Cardiac region and (B). Fundic region showing the mucosa $(\mathrm{M})$, gastric glands $(\mathrm{G})$, submucosa $(\mathrm{SM})$, internal muscular layer (I), external muscle layer (E), serosa $(\mathrm{S}), \mathrm{HE}(\mathrm{bar}=500 \mu \mathrm{m})$. (C). Pyloric region highlighting the mucosa (M), submucosa (SM), internal muscle layer (I), external muscle layer (E), serosa (S), HE (bar $=500 \mu \mathrm{m})$. (D). Detail of the cardiac region showing the mucosa $(\mathrm{M})$, gastric glands $(\mathrm{G})$ and oxynthic and peptic cells (arrow), $\mathrm{HE}(\mathrm{bar}=200 \mu \mathrm{m})$. (E). Detail of the fundic region showing the mucosa $(\mathrm{M})$, gastric glands $(\mathrm{G}), \mathrm{HE}(\mathrm{bar}=200 \mu \mathrm{m})$.

herbivorous (Villares Junior et al. 2011). Possibly those species have the same feeding habits, but the position of the mouth might indicate that they feed at different heights of the water column. Sampaio and Goulart (2011), however, reported the need for more studies analyzing the morphology of the oral cavity, due to its influence on the diet of fish. The lips of teleosts have biological importance as they are the primary detectors for food capture and have specialised chemoreception cells (Kapoor et al. 1975). In S. knerii, we identified taste buds on the lip epithelium, similar to Prochilodus argenteus, Prochilodus costatus, Leporinus reinhardti and Brycon orthotaenia (Menin 1988). In fact, fish are the only vertebrates that have taste buds in the epithelium of the head, the lips, the oral and oropharynx cavities as well as in the oesophagus (Hansen et al. 2002, Hanke et al. 2008, Xiong et al. 2011), making food 

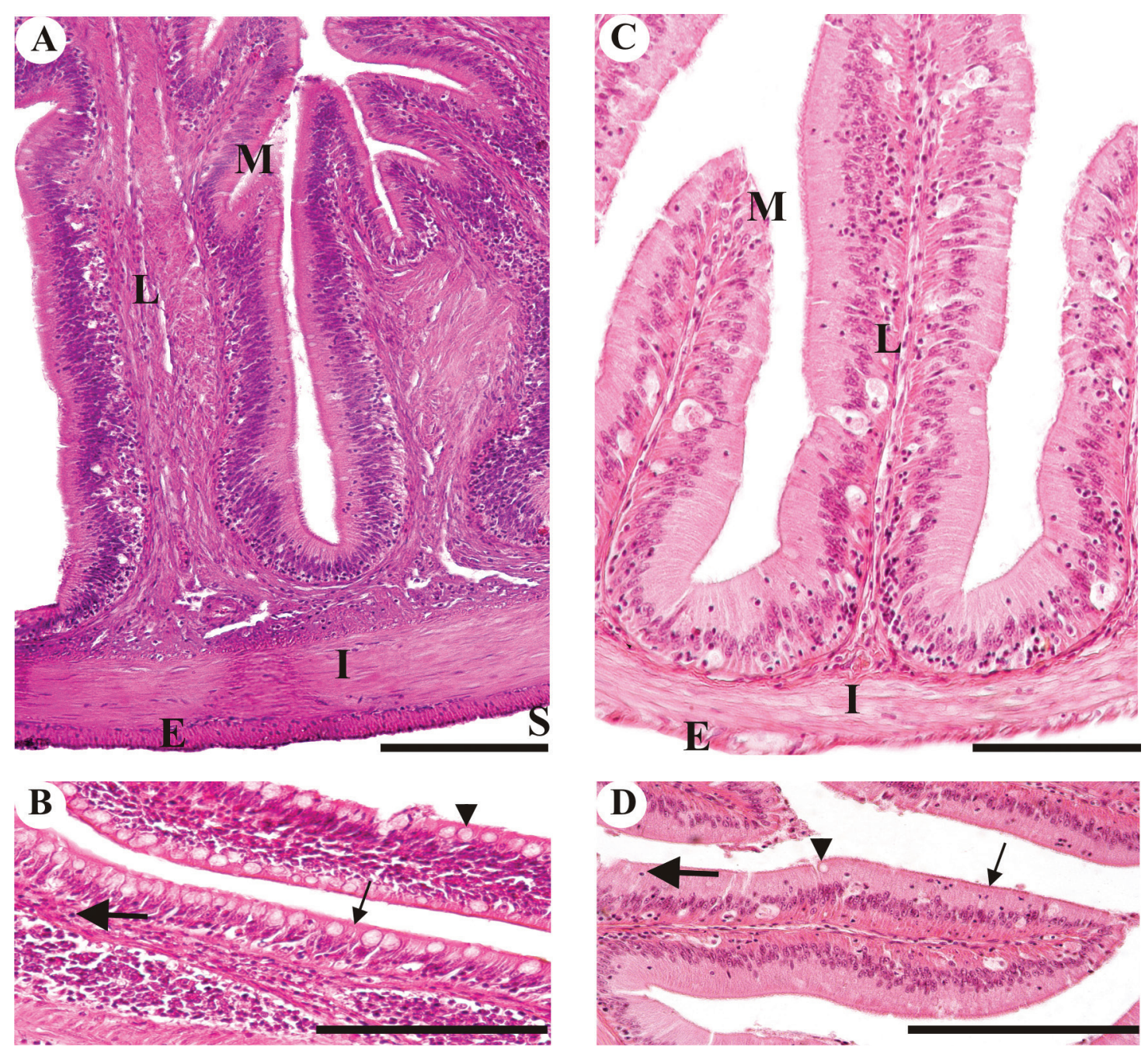

Fig. 3 - Histological organization of the intestine and pyloric caeca: (A). Cross-section of the intestine showing the mucosa (M), lamina propria (L), internal muscular layer (I), external muscular layer (E), serosa (S), HE (bar = 200 $\mu \mathrm{m})$. (B). Detail of the mucosa (M) showing goblet cell (arrowhead), lymphocyte (thick arrow), brush border (thin arrow), HE (bar $=100 \mu \mathrm{m})$. (C). Cross section of pyloric caeca showing mucosa layer (M), lamina propria (L), internal muscular layer (I), external muscular layer $(\mathrm{E}), \mathrm{HE}(\mathrm{bar}=200 \mu \mathrm{m})$. (D). Mucosa layer of the pyloric caeca showing goblet cell (arrowhead), lymphocyte (thick arrow), brush border (thin arrow), HE (bar = $100 \mu \mathrm{m})$.

identification quicker. Mucous cells are distributed in the integument and in the digestive tract of teleosts (Gona 1979, Leknes 2013) and the presence of those cells in the lips of fish have been described by Agrawal and Mittal (1992) and Xiong et al. (2011) but the chemical importance of this content is seldom discussed in the literature. In this study, those cells reacted positively to PAS, amylase + PAS, $\mathrm{Ab} \mathrm{pH} 2.5$ and $\mathrm{Ab} \mathrm{pH} 0.5$ techniques, thus suggesting its action on epithelium humidification and against pathogens. Incisiform teeth, suitable for cutting food, were observed in S. knerii, consistent with this species' herbivorous eating habits (Alvim and Peret 2004). In our study, S. knerii presented a rectangular tongue with a rounded apex, as observed in Leporinus reinhardti (Menin 1988). The species Wallago attu and Catla catla presented tongues with a stratified squamous epithelium with taste buds, 
TABLE I

Histochemical characteristics of secretion present in digestive tract.

\begin{tabular}{|c|c|c|c|c|c|c|c|c|}
\hline \multirow{3}{*}{ Histochemistry } & \multirow{3}{*}{$\frac{\text { Lips }}{\text { Mucous cells }}$} & \multirow{3}{*}{$\frac{\text { Tongue }}{\text { Mucous cells }}$} & \multirow{3}{*}{$\begin{array}{c}\text { Oesophagus } \\
\text { Mucous cells }\end{array}$} & \multirow{2}{*}{\multicolumn{3}{|c|}{$\begin{array}{c}\text { Stomach } \\
\text { Prismatic cells }\end{array}$}} & \multirow{3}{*}{$\begin{array}{c}\text { Intestine } \\
\text { Globet cells }\end{array}$} & \multirow{3}{*}{$\begin{array}{c}\text { Pyloric Caeca } \\
\text { Globet cells }\end{array}$} \\
\hline & & & & & & & & \\
\hline & & & & $\mathrm{C}$ & $\mathrm{F}$ & $\mathrm{P}$ & & \\
\hline Periodic Acid Schiff (PAS) & + & + & + & + & + & + & + & + \\
\hline Amylase + PAS & + & + & + & + & + & + & + & + \\
\hline Alcian blue pH 2,5 & + & + & + & - & - & + & + & + \\
\hline Alcian blue pH 0,5 & + & + & + & - & - & + & + & + \\
\hline
\end{tabular}

Stomach regions $(\mathrm{C})$ cardiac, $(\mathrm{F})$ fundic, $(\mathrm{P})$ pyloric; $(+)$ positive reaction, $(-)$ negative reaction.

mucous and claviform cells (Kapoor 1957), whereas in $S$. knerii claviform cells were not detected. The mucous cells of $S$. knerii reacted positively to PAS, amylase + PAS, $\mathrm{Ab} \mathrm{pH} 2.5$ and $\mathrm{Ab} \mathrm{pH} 0.5$, suggesting that those mucosubstances facilitate the passage of food in the digestive tract. The pharyngeal teeth are important in the initial processing of food and direct it to the oesophagus (Menin and Mimura 1991). The features described for $S$. knerii in the present study were similar to what has been described for other Anastomidae, such as Leporinus reinhardti (Menin and Mimura 1991) and Leporinus macrocephalus (Rodrigues et al. 2006).

The oesophagus of teleosts is described as a tubular organ, usually short and elastic which unites the oropharynx cavity to the stomach (AlHussaini 1949, Bértin 1958, Wilson and Castro 2011). The pleated aspect along the mucosa in $S$. knerii indicated an adjustment to distend the esophagus facilitating the intake of larger amounts of food, and follows the patterns described for Leporinus macrocephalus (Rodrigues et al. 2008) and Steindachnerina notonota (Silva et al. 2005). The stratified squamous epithelium described for Leporinus friderici (Albrecht et al. 2001), Prochilodus argenteus, Prochilodus costatus (Menin et al. 2006) and Serrasalmus nattereri (Raji and Norouzi 2010) was similar to that observed in $S$. knerii, and may protect the mucosa against abrasion and microorganism invasion. In the oesophageal epithelium of teleosts there are taste buds as well as epithelial, mucous, and claviform cells (Santos et al. 2007, Xiong et al. 2011). In the present study, only taste buds, epithelial and mucous cells were observed. The mucous cells reacted positively to PAS, amylase + PAS, $\mathrm{Ab}$ pH 2.5 and $\mathrm{Ab} \mathrm{pH}$ 0.5 , in agreement with the species studied by Domeneghini et al. (1998) and Santos et al. (2007). According to Albrecht et al. (2001), the species Leporinus friderici and Leporinus taeniofasciatus, which are omnivores, did not have taste buds in the oesophageal epithelium, while $S$. knerii, which is herbivorous (Alvim and Peret 2004), presented taste buds only in the cranial region of oesophageal epithelium, suggesting that the feeding habits are not related to the taste buds of this region, and their function would be associated to chemical identification. Adipose tissue was observed in the sub-mucosa layer of $S$. knerii, as in the anostomids Leporinus friderici and Leporinus taeniofasciatus (Albrecht et al. 2001). That tissue's function is related to energy reserves, as reported by Danguy et al. (1985). Still, in the present study, branched tubuloacinar oesophageal glands were identified in the sub-mucosa, which reacted positively to PAS, amylase + PAS, Ab pH 2.5 and $\mathrm{Ab} \mathrm{pH} 0.5$, 
corroborating the claim of Vegas-Velez (1972) that there are tubular glands and tubulosa acinar glands in the oesophagus of teleosts, whose secretion lubricates and protects the mucosa, thus facilitating the passage of food. The oesophageal muscular layer of $S$. knerii showed striated muscle fibres as in the anostomids Leporinus friderici, Leporinus taeniofasciatus (Albrecht et al. 2001), indicating that this type of muscle enables the contraction of the organ to drive the food into the stomach.

In the present study, the stomach exhibited a "U" shape, with defined cardiac, fundic and pyloric regions, similar to the species Prochilodus lineatus (Moraes et al. 1997). The prismatic epithelium of $S$. knerii was similar to that of the other anostomids, such as Leporinus taeniofasciatus and Leporinus friderici (Albrecht et al. 2001). The prismatic cells of the stomach's epithelium of $S$. knerii reacted positively to PAS, amylase + PAS, but only the pyloric region ones reacted positively to $\mathrm{Ab} \mathrm{pH} 2.5$ and $\mathrm{Ab} \mathrm{pH} 0.5$. The presence of neutral glycoproteins and acidic glycoconjugates in the stomach may be related to mucosal protection against mechanical and chemical damage, as reported by Petrinec et al. (2005). The gastric glands are composed of oxynthic and peptic cells, similar to the main and parietal cells in the stomach of mammals secreting pepsinogen and hydrochloric acid (Santos et al. 2007, Wilson and Castro 2011). In S. knerii, gastric glands were observed only in the cardiac and fundic regions, indicating greater demand for secretion for food processing. The muscular layer of $S$. knerii stomach showed smooth muscle fibres and loose connective tissue, which were also described by Santos et al. (2007), suggesting that gastric motility and thickening of the pyloric region enhance the movements for passing food into the intestine.

Fish intestine is a tubular organ, varying in length according to feeding habits (Angelescu and Gneri 1949, Al-Hussaini 1949, Bértin 1958). According to those authors, carnivorous fish have short intestines whereas herbivorous and iliophagous fish have a long intestine. In S. knerii, which is herbivorous (Alvim and Peret 2004), the intestine length was $302.1 \pm 47.15 \mathrm{~mm}$ and the intestinal coefficient $(\mathrm{CO})$ was $1.30 \pm 0.17$. This value of $\mathrm{CO}$ was similar to that of the herbivorous species Schizodon borellii (1.35) and Schizodon altoparane (1.41) (Ferretti et al. 1996). However, the species Leporinus taeniofasciatus and Leporinus friderici, which are omnivorous, presented $\mathrm{CO}$ values of $1.14 \pm 0.07$ and $1.25 \pm 0.15$, respectively, close to the former species (Albrecht et al. 2001). For those authors, the use of $\mathrm{CO}$ alone is not enough to determine the specialisation degree within a given diet, although Kapoor et al. (1975) reported that the intestine length naturally responds to changes in the nutritional conditions and the development stages. The intestine's epithelium of $S$. knerii is simple and of a prismatic type with goblet cells, as observed in Pseudoplatystoma fasciatum (Rodrigues et al. 2009) and Glyptosternun maculatum (Xiong et al. 2011). Goblet cells are common in the intestinal mucosa of fish (Kapoor et al. 1975) and they have been reported in recent studies as producing mucosubstances (Xiong et al. 2011, Løkka et al. 2013). In the present study, they reacted positively to PAS, amylase + PAS, $\mathrm{Ab} \mathrm{pH} 2.5$ and $\mathrm{Ab} \mathrm{pH} \mathrm{0.5,} \mathrm{indicating} \mathrm{the} \mathrm{presence} \mathrm{of}$ neutral glycoproteins and carboxylated and sulphated glycoconjugate acids. Those mucosubstances may be associated with the lubrication of the intestine mucosa that facilitate the transport of food macromolecules, as well as their absorption. Pyloric caeca are finger-like structures that connect to the intestine immediately after the pyloric sphincter and are only found in fish (Seixas Filho et al. 2000). This structure, however, may be absent in Siluriformes, as observed in Clarias batrachus (Raji and Norouzi 2010) and Glyptosternum maculatum (Xiong et al. 2011). The number and length of pyloric caeca vary among species and may be related to dietary habits. Angelescu Gneri (1949) recorded about 3000 pyloric caeca in Prochilodus lineatus, Seixas Filho et al. (2000) observed 8-13 in Leporinus friderici and 
in that study 11-15 pyloric caeca were recorded, measuring $24.5 \pm 9.1 \mathrm{~mm}$ in length. Histologically, the pyloric caeca of $S$. knerii presented mucosa with simple prismatic epithelium, with goblet cells interspersed with epithelial cells, similar to the intestine's epithelium, which has an absorptive function, thus indicating that the pyloric caeca of $S$. knerii have the same function. The goblet cells of the pyloric caeca reacted positively to PAS, amylase + PAS, Ab pH 2.5 and $\mathrm{Ab}$ pH 0.5, thus showing the presence of neutral and acid sulphated glycoproteins, a result which was also found in the pyloric caeca of Steindachnerina notonota (Silva et al. 2005).

In summary, $S$. knerii showed the following morphological characteristics of the digestive tract: incisiform teeth, a long intestine, an intestinal coefficient value of $1.30 \pm 0.17$, which are compatible with the feeding habits of herbivorous fish. The results also showed that the anatomical, histological and histochemical structure, described for the first time for the genus Schizodon, provide information to better understand $S$. knerii's digestive tract morphology, and expands knowledge for future studies. Moreover, the presence of mucosubstances in the epithelium lining throughout the tract highlights the importance of those glycoproteins in the feeding process of the species. This knowledge increases our understanding of $S$. knerii, which is important for human feeding and for professional fishing.

\section{ACKNOWLEDGMENTS}

The authors wish to thank Coordenação de Aperfeiçoamento de Pessoal de Nível Superior (CAPES), Fundação de Amparo à Pesquisa do Estado de Minas Gerais (FAPEMIG) and PUC Minas PROBIC for their financial support; Rubens Miranda and Rogério Matos for preparing the histologic slides, and Cássio Coletinha Xavier and Elvira Cynthia Alves Horácio, from the PUC Minas Biology Information Treatment Lab, for helping with the photographic documentation.

\section{RESUMO}

O trato digestório de 44 exemplares de Schizodon knerii foi estudado utilizando técnicas anatômicas, histológicas e histoquímicas. Boca tem posição terminal, epitélio labial é estratificado pavimentoso com células mucosas, claviformes e botões gustativos, dentes são incisiviformes, língua tem epitélio pavimentoso estratificado com células mucosas e botões gustativos. Cavidade bucofaringe é constituída pelos aparelhos branquial e dentário faringeano. Esôfago mostrou mucosa pregueada, epitélio pavimentoso estratificado, com células mucosas, glândulas esofágicas e botões gustativos. Estômago apresentou as regiões cárdica, fúndica e pilórica, epitélio simples prismático, com glândulas tubulosas e nenhuma na pilórica. Intestino contém de 11 a 15 cecos pilóricos, epitélio é simples prismático com borda em escova, células caliciformes e linfócitos. Células mucosas, glândulas esofágicas e células caliciformes reagiram positivamente ao PAS, amilase + PAS, Ab pH 2.5 e Ab pH 0.5. Células prismáticas gástrica foram positivas ao PAS, amilase + PAS e apenas as da região pilórica regiram positivamente ao $\mathrm{Ab} \mathrm{pH} 2.5$ e $\mathrm{Ab} \mathrm{pH}$ 0.5. Os resultados fornecem informações acerca do entendimento das estruturas anatômicas e celulares envolvidas na alimentação de S. knerii e a presença de mucossubstâncias no epitélio evidencia a importância dessas glicoproteínas durante a passagem do alimento no trato digestório.

Palavras-chave: Anostomidae, trato digestório, peixe, morfologia.

\section{REFERENCES}

AgRAWAL N AND MitTAL AK. 1992. Structure and histochemistry of the epithelia of lips and associated structures of a catfish Rita rita. Jpn J Ichthyol 39: 93-102.

ALBRECHT MP, FERREIRA MFN AND CARAMASCHI EP. 2001. Anatomical features and histology of the digestive tract of two related neotropical omnivorous fishes (Characiformes; Anastomidae). J Fish Biol 58: 419-430.

AL-HussainI AH. 1946. The anatomy and histology of the alimentary tract of the coral feeding, Mulloides auriflamma (Forsk.). J Morph 78: 121-154.

AL-HussainI AH. 1949. On the functional morphology of the alimentary tract of some fish in relation to differences in their feeding habits: Anatomy and histology. Q J Microsc Sci 90: 109-139. 
Alvim MCC AND Peret AC. 2004. Food resources sustaining the fish fauna in a section of the upper São Francisco River in Três Marias, MG, Brazil. Braz. J Biol 64: 195-202.

ANGELESCU V AND GNERI FS. 1949. Adaptaciones del aparato digestivo al regime alimentício en algunos peces del rio Uruguay y del rio de La Plata. Rvta Inst Nac Invest Ciênc Nat 1: 161-281.

Barbosa JM AND SoAres EC. 2009. Perfil da ictiofauna da Bacia do São Francisco: Estudo preliminar. Rev Bras Enga Pesca 4: 155-172.

BÉRTIN L. 1958. Appareil digestif. In: Grassé PP. Paris Masson. Traité de zoologie 13: 1248-1302.

Britski HA, SATO Y AND RosA ABS. 1986. Família Anostomidae. In: Britski HA, Sato Y and Rosa ABS. Manual de identificação de peixes da região de Três Marias: com chaves de identificação para os peixes do São Francisco, Brasília: Câmara dos Deputados, 182 p.

BRASIL. 2013. Ministério da Ciência, Tecnologia e Inovação. Diretrizes da prática de eutanásia do CONCEA. Brasília: CONCEA, $54 \mathrm{p}$.

DAnguy A, Lenglet G AND Kiss RB. 1985. Histological characteristics of the esophagus of Phractolaemus ansorgei (Pisces, Gonorhynchiformes). Cybium 9: 193-202.

DiAZAO, GARCÍAAM, DEVINCENTICV AND GOLDEMBERG AL. 2003. Morphological and histochemical characterization of the mucosa of the digestive tract in Engraulis anchoita. Anat Histol Embryol 32: 341-346.

Domeneghini C, Panneli RS And Veggetti A. 1998. Gut glycoconjugates in Sparus aurata L. (Pisces, Teleostei). A comparative histochemical study in larval and adult ages. Histol Histopathol 13: 359-372.

Ferretti CML, ANDrian IF AND TORRENTE G. 1996. Dieta de duas espécies de Schizodon (Characiformes, Anostomidae), na planície de inundação do Alto Paraná e sua relação com aspectos morfológicos. Bol Inst Pesca 23: 171-186.

GARAVELlo JC AND BRITSKI HA. 2003. Family Anostomidae (Headstanders). In: Reis RE, Kullander SO, Ferraris Jr and Carl J. Cheklist of the freshwater fishes of South and Central America. Porto Alegre: Editora Universitária da PUCRS, p. 71-84.

Germano RM, Stabille SR. MARI RB, Pereira JNB, Faglioni JRS AND Miranda Neto H. 2013. Morphological characteristics of the Pterodoras granulosus digestive tube (Valenciennes, 1821) (Osteichthyes, Doradidae). Acta Zool DOI: 10.1111/azo.12016.

GoNA O. 1979. Mucous glycoproteins of teleostean fish: a comparative histochemical study. Histochem J 11: 709-718.

GUISANDE CETAL. 2012. Ecological Factors and Diversification among Neotropical Characiforms. Int J Ecol 2012: 1-20.

Hanke BV, Meyer AA AND Oliveira E. 2008. Análise histológica de estruturas sensoriais de Centropomus parallelus (Poey, 1896) (Centropomidae) relacionadas ao hábito alimentar. RUBS 1: 16-23.

Hansen A, Reutter K AND Zeiske E. 2002. Taste bud development in the Zebrafish, Danio rerio. Dev Dyn 223: 483-496.
KAPOOR BG. 1957. A study on the tongue of fishes. Jap J Ichth 6: 82-86.

KAPOOR BG, SMIt H AND VerighinA IA. 1975. The alimentary canal and digestion in teleosts. Adv Mar Biol 13: 109-239.

LEKNES IL. 2013. Goblet Cell Types in Intestine of Tiger Barb and Black Tetra (Cyprinidae, Characidae: Teleostei). Anat Histol Embryol DOI: 10.1111/ahe.12083.

LøKKA G, AustBo L, FALK K, BJERKÅs I AND KopPANG EO. 2013. Intestinal morphology of the wild atlantic salmon (Salmo salar). J Morphol 274: 859-876.

MENIN E. 1988. Anátomo-histologia funcional comparativa do aparelho digestivo de seis Teleostei (Pisces) de água doce [Tese]. São Paulo: Universidade de São Paulo. 402 p. Available from: Universidade de São Paulo, Instituto de Biociências, D415.

Menin E AND MimURA OM. 1991. Anatomia funcional da cavidade bucofaringiana de duas espécies de Teleostei de água doce, Leporinus reinhardti Lütken, 1874, e Brycon lundii Reinhardt, 1849, de hábito alimentar onívoro. Ceres 38: 345-372.

Menin E, Rodrigues SS AND Mimura OM. 2006. Histologia do esôfago de Prochilodus marggravii (Walbaum, 1792) e Prochilodus affinis Reinhardt, 1874 (Characiformes, Prochilodontidae). IVCongreso Iberoamericano Virtual de Acuicultura.

Moraes MFPG, BARbola IF AND Guedes AC. 1997. Alimentação e relações morfológicas com o aparelho digestivo do "curimbatá", Prochilodus lineatus (Valenciennes) (Osteichthyes, Prochilodontidae), de uma lagoa do sul do Brasil. R Bras Zootec 14: 169-180.

PEARSE AGE. 1985. Histochemistry - Theoretical and Applied. Edinburgh: Churchill Livingstone, 613 p.

Petrinec Z, NeJedli S, KuZIR S AND OpacaK A. 2005. Mucosubstances of the digestive tract mucosa in northern pike (Esox lucius L.) and european catfish (Silurus glanis L.). Vet arhiv 75: 317-327.

RAJI AR AND NOROUZI E. 2010. Histological and histochemical study on the alimentary canal in Walking catfish (Clarias batrachus) and piranha (Serrasalmus nattereri). Iranian J Veterinary Res 11: 255-261.

Rodrigues APO, PAUletti P, Kindlein L, Cyrino JEP, DElgado EF AND MAChADO-Neto R. 2009. Intestinal morphology and histology of the striped catfish Pseudoplatystoma fasciatum (Linnaeus, 1766) fed dry diets. Aquacult Nutr 15: 559-563.

RodRIGUES SS AND MENIN E. 2005. Anatomia da cavidade bucofaringeana de Conorhynchos conirostris (Valenciennes, 1984) (Siluriformes). Ceres 52: 843-862.

Rodrigues SS AND MENIN E. 2008. Anatomia do tubo digestivo de Salminus brasiliensis. (Cuvier, 1817) (Pisces, Characidae, Salmininae). Biotemas 21: 65-75.

RODRIGUES SS, NAVARRO RD AND MENIN E. 2006. Adaptações anatômicas da cavidade bucofaringiana de Leporinus macrocephalus Garavello e Britski, 1988 (Characiformes, Anostomidae) em relação ao hábito alimentar. Biotemas 19: 51-58. 
Rodrigues SS, NAVARro R AND MENIN E. 2008. Anatomia do tubo digestório de Leporinus macrocephalus Garavello \& Britski, 1988 (Characiformes, Anostomidae) em relação ao seu habita alimentar. Biosci J 24: 86-95.

SAMPAiO ALA AND GoUlarT E. 2011. Ciclídeos Neotropicais: Ecomorfologia trófica. Oecologia Australis 15: 775-798.

SANTOS CM, DUARTE S, SOUZA TGL, RIBEIRO TP, SALES A AND ARAÚJO FG. 2007. Histologia e caracterização histoquímica do tubo gastrintestinal de Pimelodus maculatus Pimelodidae, Siluriformes) no reservatório de Funil, Rio de Janeiro, Brasil. Iheringia Sér Zool 97: 411-417.

SATO Y AND BARBIERI G. 1982. Crescimento de Schizodon knerii Steindachner, 1875 (Pisces, Anostomidae) na represa de Três Marias, Minas Gerais. An Sem Reg Ecol 3: 201-221.

SeIXAs-Filho JT, BrÁs JM, Gomide ATM, OliVEIRA MGA, DonZele JL AND MENIN E. 2000. Anatomia funcional e morfometria dos intestinos e cecos pilóricos do teleostei (Pisces) de Água Doce Piau (Leporinus friderici, Bloch, 1794). Rev Bras Zool 29: 2181-2192.

Silva NB, GURGEL HCB AND SANTANA MD. 2005. Histologia do sistema digestório de sagüiru, Steindachnerina notonota (Miranda Ribeiro, 1937) (Pisces, Curimatidae), do rio Ceará Mirim, Rio Grande do Norte, Brasil. Bol Inst Pesca 31: 1-8.
SOARES MG, DABÉS AC, SATO Y, BAZZOLI N, RIZZO E AND FERREIRA RMA. 1996. Tamanho de primeira maturação sexual do Schizodon knerii e do Leporinus piau (Teleostei, Anostomidae) na represa de Três Marias, MG. Arq Bras Med Vet Zootec 48: 47-54.

VegAS-VELEZ M. 1972. La structure histologique typique du tube digestif des poissons téleosteens. Tethys 4: 163-174.

Villares Junior GA, Gomiero LM AND GoITEIN R, 2011 Biological aspects of Schizodon nasutus Kner, 1858 (Characiformes, Anostomidae) in the low Sorocaba river basin, São Paulo state, Brazil. Brazil. Braz J Biol 71: 763-770

WiLson JM, CASTRO LFC. 2011. Morphological diversity of the gastrointestinal tract in fishes. In: Grossell M, Farrell AP, Brauner CJ. The multifunctional gut of fish. New York: Academic Press, p. 2-44.

Xiong D, Zhang L, Yu H, Xie C, Kong Y, Zeng Y, Huo B AND LIU Z. 2011. A study of morphology and histology of the alimentary tract of Glyptosternum maculatum (Sisoridae, Siluriformes). Acta Zool 92: 161-169. 